\title{
NEW ROADS TOW ARD THE SETTLEMENT OF FEDERAL INCOME, ESTATE, AND GIFT TAX CONTROVERSIES
}

\author{
Rogrr John Traynor* and Stanley S. Surrey†
}

The expansion of governmental functions has intensified the dual problem of finding adequate public revenues and distributing the burden of taxation equitably among taxpayers according to their ability to pay. The revenue laws must be as delicately planned as the arrangement of cargo for the hold of a ship if they are to equilibrate the incidence of a variety of taxes. Their complexity sometimes mystifies taxpayers but it also protects them, for graduaied rate structures, exemptions, deduction provisions and the like are guarantees that the weight of their tax burdens will be measured ones. It is inevitable, however, that the growth of those burdens in size and complexity has placed greater stakes at issue between the taxpayer and the government, multiplied the number of coniroversial issues, and therefore sharpened the spirit of controversy on each side. Litigation is abroad in the land to obstruct the effective collection of the revenues. It would only flare up the more under a simplification of the revenue laws which would rudely level away detailed provisions for the equitable adjustment of tax burdens. It is pertinent, however, to inquire whether it cannot be minimized through a more effective administrative and judicial procedure for the settlement of controversies.

It is a tribute to the cooperation between taxpayers and government that while controverted cases involved amounts out of all proportion to their number, they represent only $5 \%$ of the average seven million annual returns, based entirely on self-assessment, which the government receives in the field of income taxation alone. Such controversies arise because the taxpayer has failed unintentionally or deliberately to make an accurate self-assessment, or because the government has erred in its own appraisal of the taxpayer's liability, or because there is a valid issue between them

\footnotetext{
-A.B., 1923, Ph.D., 1927, J. D., 1927, University of California. Member of the California Bar. Professor, University of California School of Law, Acting Dean, 1939-1940. Consultant, California State Board of Equalization, since 1932. Consulting expert, U. S. Treasury Department, 1937-1938. Contributor to legal periodicals.

tB.S., 1929, College of the City of New York; LL.B., 1932, Columbia University. Member of the New York Bar. Assistant Legislative Counsel, United States Treasury Department. Contributor to legal periodicals.

Although one of the writers is employed by the United States Treasury Department, the views expressed herein are entircly those of the writers and nothing herein shall be taken as the official opinion of the Treasury Department.
} 
which might be resolved with equal reason for either side. Because they involve major issues and large sums of money their settlement is of far-reaching importance. Yet the administrative and judicial procedure which governs them has in its haphazard development long been a tortuous maze deflecting rather than speeding the course of settlement.

\section{AdiInIstrative Procepure}

The entire administrative machinery engendered by the adoption of the income tax was originally centralized in Washington. The war and post-war years brought in their wake a volume of tax litigation so complex and widespread as to defy solution so long as the efforts at solution were concentrated in the capital. Decentralization became urgent, and in the early nineteen twenties the Bureau of Internal Revenue took the first steps in that direction, a tropistic response to current exigencies rather than a plan. The Internal Revenue Agents in charge of various geographic subdivisions received authority to conduct conferences. and settle disputed cases. Thereafter the Committee on Appeals and Review adopted the practice of hearing cases outside of Washington. It was superseded in 1924 by the present Board of Tax Appeals, whose decisions were in 1926 made subject to review by the Circuit Courts of Appeals and the Court of Appeals for the District of Columbia. The Board slowly developed its circuit calendars and the hearings which it held in various cities compelled the presence of attorneys from the Appeals Division of the Bureau of Internal Revenue and Technical Staff members.

Duplicate procedures and overlapping administrative and judicial functions settled into the folds of this pragmatic development, and entrenched themselves over the years through the inertia of taxpayers and government. They have engendered delays and uncertainties of such proportions as to threaten seriously the protection both of the taxpayer's interest and of the government's revenues. In view of the honesty of the overwhelming number of taxpayers and the high caliber of the government's tax administrators, factors which would normally expedite disposition of the cases, the halting and creaking of the settlement procedure seems due to internal causes.

Over a year' ago a survey of this procedure marshalled the evidence of its chronic weaknesses. ${ }^{1}$ The picture that emerged therefrom resembies an hour glass in which the sands of litigated cases fall from their administrative container into the narrow radius of the Board of Tax Appeals only to be imprisoned therein in a curicus sifter which slowly strains a few of them into the inverted form of judicial review, but spouts the great number back for administrative settlement. For many years there has been little variation in the vast amounts repzesented by the litigation which has thus proceeded along unpredictable paths to settlement, and both the taxpayer and the government have watched the process with increasing concern. At the close of the fiscal year 1938-1939 there were 7,864 cases involving $\$ 456,974,846$ pending before the

\footnotetext{
${ }^{2}$ Traynor, Administratice and Isdicial Procedure for Federal Income, Estate, and Gitt Tax Cases (1938) 38 COL L REv. 1393 .
} 
Board of Tax Appeals and the courts that review its decisions. Before the Board itself there were 6,574 cases. ${ }^{12}$ It is impossible for the Board to hear more than one fifth of that number of cases within a year, and the uninitiated may well wonder how it continues to function at all. It does so only by a process which returned for administrative settlement a jetsam nearly $71 \%$ of the cases on its calendar for the fiscal year 1938-1939, and nearly $74 \%$ in the preceding year.

If this process were a swift one it might work no harm, but its pace is that of the tortoise. The Board can consult no oracle to determine which of the cases on its jammed calendar it will itself hear, and it can derive little comfort from the fact that it is annually rescued from submersion by administrative confreres just as the waves of a new year close over it. In the interim it is under constant pressure to clear its congested calendar. Even now the number of new petitions for a Board hearing filed annually almost keeps pace with the number of cases disposed of annually. At the end of the fiscal year 1938-1939, there remained an accumulation of 6,574 cases to retard the disposition of new cases.

Meanwhile the taxpayer and the government suffer the bedevilment of uncertainty and delay. The great bulk of the petitions to the Board involve small amounts and turn on factual questions which could more appropriately have been settled at the outset by agreement between the taxpayer and the Commissioner. ${ }^{2}$ Numerically the cases settled administratively after petition to the Board represented only $2.1 \%$ of the total number administratively setuled in the typical fiscal year 1937-1938, but they tied up $15.1 \%$ of the total amount of deficiencies and peisalties. ${ }^{3}$ Their transitory appearance on the Board's calendar, from which they are transferred for administrative settlement, results in serious delay, not only in their own disposition but in that of the cases eventually heard by the Board. A study based on income tax cases closed by the Board in 1934 revealed an average spread of six years between the tax year involved and the Board's decision, and it is estimated that there is still an average spread of five years. Nor does the story end there, for many cases linger an average of almost two years before decision in the Circuit Courts of Appeals and sometimes another year before decision by the Supreme Court.

The government risks the loss of substantial amounts of revenue in these long delays during whiich the taxpayer may become unable to meet his full tax liability. Neither a bond nor any other security is required of him when he files a petition with the Board, and the petition itself stays both assessment and collection of the deficiency until determination by the Board. While the Commissioner has authority to make a jeopardy assessment whenever in his judgment the collection of a deficiency might otherwise be jeopardized, he cannot anticipate all of the cases which require such action. In the typical fiscal year of $1936-1937$ over $11 \%$, amounting to $\$ 1,745,203$, of the total amount assessed under Board decisions after hearing proved uncollectible.4 Such a leakage is serious over the years. The taxpayer meanwhile suffers the greatest uncertainty in the conduct of his personal or business affairs.

in Nearly 5000 new petitions are being filed annually.

Id. 2t 1398 .

Id. at 1395 .

-Id. at 1397. 
The congested calendar of the Board of Tax Appeals is the major symptom of a chronic delay whose causes lie elsewhere. There is something basically wrong in a procedure which enables so many cases to travel the long, expensive and futile route up to the threshold of a judicial settlement only to retrace their steps at that point to an administrative settlement or to be abandoned altogether by the taxpayer or the government. If this great mass of cases could be weeded out at the start the Board's calendar would be limited to that small number of cases which require a judicial hearing. Manifestly the critical accumulation of cases at this stage results from some breakdown in the earlier stages of administrative procedure. Evidence thereof lies in the fact that by the close of the fiscal year $1938-1939$ over $56 \%$ of the petitions filed with the Board involved amounts of less than $\$ 5,000$. while over $38 \%$ involved amounts of less than $\$ 2,000$. Even greater significance lies in the abandonment by the Commissioner of an average of about $70 \%$ of the amount of the deficiencies asserted in his ninety-day letters over the fiscal years from $1935^{\circ}$ through 1938, a percentage not appreciably lowered by the close of the fiscal year 1938-1939. In that year the Commissioner recovered only $33.6 \%$ of the total amount in controversy. ${ }^{5}$ A disputed deficiency has traditionally been subject to so many reconsiderations by so many different groups within the Bureau of Internal Revenue that settlements have often emerged less from prolonged deliberation than from cumulative confusion.

The decentralization program inaugurated by the Bureau of Internal Revenue in 1938 and concluded in 1939, to expedite the disposition of those cases which can most appropriately be settled in the early stages of the administrative procedure, is a significant step in the right direction. If it fulfills its objectives it may encourage other improvements, and therefore merits a brief description. Responsibility for cases in their early stages continues to rest with the Internal Revenue Agents in Charge. Whenever their investigation discloses grounds for the assertion of a deficiency, they send the taxpayer a preliminary thirty-day letter to that effect. The taxpayer may file a protest within thirty days and obtain a hearing in the office of the Internal Revenue Agent in Charge, who has authority to conclude the case if the conference produces an agreement. While the case is subject to review in Washington, its disposition is rarely altered. Failing an agreement the taxpayer is notified of the proposed deficiency and of his opportunity to obtain a hearing before the appropriate field division of the Technical Staff. If he does not avail himself of the opportunity, or did not originally file a protest after receiving the preliminary thirty-day letter, the Internal Revenue Agent in Charge sends him a final ninety-day statutory notice of deficiency in the name of the Commissioner. A period of 120 days from the date of the preliminary thirty-day letter is allowed on the average for the consideration of the proceeding in the office of the Internal Revenue Agent in Charge.

If an agreement cannot be reached with the Internal Revenue Agent in Charge, the taxpayer may then obtain a hearing in the appropriate field office of the Technical Staff. There are ten field divisions of the Staff, each with its own territorial juris-

\footnotetext{
${ }^{5}$ The Technical Staff conceded $59.5 \%$ in amount, the Appeals Division conceded $75.1 \%$ and Board
} decisions reduced the amount by $87.8 \%$. 
diction and several local offices. The personnel of each consists of a Head and an Assistant Head designated by the Commissioner, a Division Counsel and an Assistant Division Counsel designated by the Chief Counsel, and a number of technical ad. visors, attorneys, auditors and clerks. Each Division considers cases referred to it at the request of the taxpayer by the Internal Revenue Agents in Charge situated within its territorial jurisdiction. It will not consider, before the issuance of the statutory notice of deficiency, any case in which no protest has been filed with the Internal Revenue Agent in Charge, or in which the taxpayer does not desire Staff consideration. If the taxpayer and Technical Staff agree on the disposition of a case it can be settled by the Head of the Division without further review in Washington. Failing an agreement, a memorandum is prepared in the Staff Division setting forth the exact grounds for the assertion of the proposed deficiency. After consideration by the Division Counsel it is transmitted to the Internal Revenue Agent in Charge, who issues in the name of the Commissioner a statutory notice of deficiency based thereupon. Upon its receipt the taxpayer may obtain a hearing before the Staff Division in the ninety-day period only under such exceptional circumstances as a shift in legal interpretation or a change in the Regulations.

Once a taxpayer files a petition to the Board of Tax Appeals, the Staff Division, in an effort to settle the case administratively, generally grants him a hearing conducted by the same persons, sometimes with additional officials, who considered the case prior to the issuance of the ninety-day letter. The Division Counsel handles before the Board of Tax Appeals all cases (I) which originate within the Division and which are placed either on a calendar for hearing within the territorial jurisdiction of the Division, on the Washington calendar, or on the calendar for an adjoining Division, and (2) which, although originating in other Divisions, except an adjoining Division, are placed on a calendar for hearing within the territorial jurisdiction of the Division. Any such case may be settled administratively if the Head of the Staff Division and the Division Counsel concur, but otherwise it proceeds to a Board hearing. The Commissioner may by written order withdraw from a Staff Division any case not docketed before the Board and provide for its disposition under his personal direction, and he may in conjunction with the Chief Counsel withdraw a case docketed before the Board, provided a copy of such order and the reasons therefor are furnished to the Secretary. A taxpayer cannot otherwise have his case considered in Washington. This procedure for the cases involving deficiencies is applicable also to refund cases, except that refunds of over $\$ 20,000$ agreed to by a Staff Division are subject to review in Washington before final conclusion of the cases.

This complete decentralized consideration. of the cases has significant consequences. The taxpayer who receives a thirty-day letter realizes that he can no longer delay filing a protest until the case has been forwarded to Washington, but must do so immediately to avoid receiving a final deficiency letter. While previously he could obtain a Technical Staff hearing only by filing a petition with the Board, he can now have such a hearing before the issuance of the deficiency letter. Prcsent 
indications are that early settlements with the Internal Revenue Agents in Charge are encouraged by this right of immediate appeal to the Technical Staff. In addition, while there will always be many cases settled subsequent to the filing of a petition, a significant number of the $70 \%$ of the Board dockets now settled without Board hearing should henceforth be terminated in the administrative stage, as there is no longer any advantage in this regard in delaying consideration of a case which is heard by the same officials after the filing of a petition as before. Preliminary figures confirm this expectation, for in the last six months of 1939 there were 1,593 petitions filed with the Board, as compared with 2,049 in the corresponding period in 1938 . In the first four months of 1940 there were 1,369 petitions, as compared with 1,678 in 1939 .

Substantial improvement in deficiency letters should result from decentralization. These letters are prepared in the office of each Internal Revenue Agent in Charge by one or two especially qualified persons in all cases which do not have Technical Staff consideration. In cases appealed by the taxpayer to the Technical Staff, the deficiency letters are in effect prepared by the latter with respect to the issues appealed to it by the taxpayer and checked by the attorneys who will later be called upon to defend the letters before the Board. Here at last should be a deficiency letter which clearly states the reasons for the deficiency. The Appeals Division attorneys who must defend the cases before the Board can make known their legal views in the administrative stage and thereby forestall such last-minute concessions of the case as they have at times been compelled to make in the past. The percentage in amount of deficiencies sustained either by Board decision or settlement after petition to the Board should rise appreciably now that the interested technicians and attorneys become familiar with the deficiency letters before they result in Board petitions and have adequate time for preparation of a case in the event of a trial. Such increased preparation, moreover, makes for more stipulations of fact and shorter hearings.

Another important advantage of the decentralization program is its convenience to the taxpayer. It is simpler for him to appear with his attorney and his books and records before a Technical Staff man in his own locality than to proceed to Washington to discuss his case. He encounters in the Staff Division a single, unified agency empowered to exercise for the Commissioner all of the authority which the Department or any of its branches possesses in the review of protested tax determinations made by the Internal Revenue Agents in Charge, in the settlement of contested cases, and in the defense of proceedings before the Board.

There is little ground for the fear that the substitution of ten field divisions and thirty-eight offices of the Technical Staff for the unit previously centralized in Washington will prevent uniformity in the consideration of cases. The various offices of the Internal Revenue Agents in Charge, which consider the great bulk of cases, have for years been decentralized. The Income Tax Unit review in Washington had been divided among at least five separate audit review divisions, just as the Technical Staff review had been divided among at least twelve groups, each headed by a Senior 
Technical Advisor. The present geographical decentralization differs from such functional decentralization only in being more convenient to the taxpayer. The current development of yardsticks of general application should in fact increase uniformity. Every case concluded in the Staff Divisions is subject to a review in Washington intended not to disturb the disposition of the case but to guard against future deviations from the accepted Bureau standards. The Staff Divisions themselves customarily refer questions to Washington whenever it appears that their local consideration might result in a lack of uniformity.

A question naturally arises as to the disposition of cases involving several field divisions. Thus a distribution by a corporation may involve stockholders residing in many states. A controversy over a trust may involve a trustee in one part of the country and a beneficiary in another. A consolidated return may involve corporations in several scattered states, or the return of a single corporation may relate to properties and businesses in various parts of the country. The procedures devised over the years to deal with these special situations are still in effect and their initial consideration continues to rest with the various offices of the Internal Revenue Agents in Charge. If a case is not properly coordinated by the time it reaches a Staff Division, the latter may deal with it effectively by means of supplementary conferences held under the auspices of the other Divisions.

It is too early fully to appraise the effectiveness of the decentralization program: Present indications and preliminary figures are all on the favorable side. Its complete success will depend upon its ability to bring about an increase in the number of settlements in the Offices of the Internal Revenue Agents in Charge; a reduction in the number of deficiency letters issued and petitions filed with the Board; a reduction in the present percentages of deficiencies abandoned in the various stages of the procedure; and a general reduction in the time factor at each stage.

Many problems nevertheless remain unsolved. While there should be an increase in the already high percentage of cases settled by preliminary conferences in the field, there is still no way of insuring the effective operation of the principle of selfassessment in subsequent stages. In many instances the taxpayers are responsible for delaying settlement in the hope of securing favorable consideration of a weak case. Frequently they file Board petitions although they have failed either to file a protest with the Internal Revenue Agent in Charge, or, following a hearing by that official on their protest, to refer their cases to the Technical Staff. Settlements in the administrative stage are frustrated by this failure to utilize the settlement facilities that are available to the taxpayer. They are also blocked by his failure in many instances to disclose all of the relevant facts and documents. The Commissioner cannot afford the time or expense of wholesale investigation. He must therefore either forego assessments which might properly have been made, or risk the assertion of deficiencies which may prove unfounded. The Appeals Division attorney who files the answer is in some instances apt to have no more factual information than the Commissioner, and the Board falls heir to the task of ferreting out the facts, not uncommonly in the midst of surprise testimony and new evidence. 
As a consequence there is still no sharp line between the administrative consideration of a case and its judicial review. The filing of a petition to the Board should mark the end of administrative and the beginning of judicial consideration. Actually the case is for all practical purposes still in the administrative stage for an average of two years more. Since neither the taxpayer nor the government can avoid the day of reckoning, and the accuracy of the final reckoning depends not upon repeated preliminary considerations but upon the availability of all the pertinent facts, it is of the greatest importance to find some catalytic agent which will yield the facts in the administrative stage.

The analysis of the existing procedure which appeared in the Columbia Law Review over a year ago $^{6}$ contains certain proposals in this regard which are here briefly set forth. The Commissioner, in notifying the taxpayer of a proposed deficiency, could advise him at the same time of the opportunity to file a protest within ninety day's to six months. It would be entirely feasible to require such a protest, unlike the present protest, to set forth fully the grounds of protest, all the relevant evidentiary. and ultimate facts, a list and location of relevant books and papers, and the names and addresses of persons having knowledge of the facts, together with a brief statement of their connection with the transactions in question. The taxpayer might have considerable latitude in the detail of presentation of such a protest, according to the circumstances and complexity of his case, and amplification might be required only to protect him from the assertion of deficiencies by the Commissioner which could not be later substantiated. Both parties would then have an assurance that any. subsequent disagreement would turn largely upon questions of law and not of fact. Pursuant to the filing of such a protest, the taxpayer could avail himself of another informal conference in the field with a trained technician familiar with his problem and its local background. If this conference failed to produce agreement, the Commissioner could be required to include specific findings of fact in his final notice of deficiency.

The proposed protest procedure rests upon the proposition that a full disclosure of the facts by the taxpayer at an early stage is essential to an expeditious and intelligent disposition of his case. Certainly it is the most effective means of protecting him against unnecessary litigation. Since only exceptionally difficult problems should reach the stage of protest procedure through which the taxpayer would appeal his case to the final administrative authority, there would be all the more reason to assemble all the relevant facts at this stage. There is at stake the interests not only of the taxpayer in the controverted case, but of all other taxpayers who sooner or later might find themselves in a comparable factual situation. It is likewise important to the Commissioner to be aware of all of the facts in determining the taxpayer's liabitity, if his determinations are to have the presumption of correctness. In practice the protest requirements should operate to encourage a disclosure of all the facts in the preliminary conference, and in any event should facilitate a settlement of at least the factual issues before the case proceeded to the judicial stage.

- Traynor, sapra note 1 . 
Severe protest requirements could tighten up the loose bearings in the administrative machinery without impairing that flexibility so necessary to meet the varing circumstances of different cases. The taxpayer would have ample opportunitics for conference in the preliminary administrative stage. If any new material came to light or became relevant as a result of conferences on the protest, the taxpayer would be free to amend the protest at any time before determination thereon by the Commissioner, and the latter could in his discretion make his own investigation at this. stage. If the taxpayer chose thereafter to present his case to the Board of Tax Appeals, he would be limited as a general rule to the grounds, facts and documents outlined in his protest, just as the Commissioner would be enjoined from presenting any claim before the Board for an additional deficiency. The Board would have before it not the vague deficiency letter of the past but the detailed determination and findings of fact of the Commissioner. It would likewise be limited to the issue presented by the findings of fact and the protest.

These limitations could easily be relaxed in appropriate circumstances. Thus in the interval between the Commissioner's determination and the Board's hearing the courts might lay down a rule of law which would lend significance to facts not hitherto considered relevant. The Board itself might adopt a view of the facts differing from that of the taxpayer and the Commissioner." Under such circumstances it might allow either party to present new facts or theories provided they related only to the transactions covered by the protest and findings of fact, even though other transactions also affected the tax liability. The burden of proof to upset the findings would rest upon the taxpayer, as it does at present with respect to the assertion of a deficiency. ${ }^{7 *}$ In sustaining that burden the taxpayer would be at liberty as he is today to prove either that the Commissioner's findings are not supported by any evidence or that they are contrary to the weight of the evidence.

These proposals have aroused a tempest of criticisms in a teapot of misunderstanding. ${ }^{8}$ Underlying some of them is a not always clearly defined sentiment that the taxpayer stands to lose from the clarification of his case, or that he would have to call for expert assistance at an earlier stage to make that clarification possible. In actual practice, however, the taxpayer has been his own lawyer or accountant in only $4.2 \%$ of the cases closed by the Technical Staff, $6.7 \%$ of the cases settled by the Appeals Division and $5.6 \%$ of the cases decided by the. Board-cases which would be principally affected by the protest requirement. Moreover, one of the basic causes today of inadequate disclosure of the essential facts is the frequent failure of the taxpayer's representative to study his case carefully and to marshall the pertinent facts

${ }^{\top}$ Id. at 1419 , ni: 47 ..

7a See 5 PAUI \& Mertens, Federal Isconge Taxatros (1934) 543.56.

- See Angell, Procedural Reform in the ludicial Review of Controversies under the Internal Revenue Statutes; An Answer to a Proposal (1939) 34 ILL. L. Rev. 151; Youngquist, Proposel Radical Changes in the Federal Tax Machinery (1939) 25 A. B. A. J. 291; Seidman, Proposed Procedural Changes in Federal Tax Practice (1939) $67 \mathrm{~J}$. of Accountancy 221; Prettyman, The Traynor Proposals-Some Considerations (1939) 17 TAxEs 397; Prettyman, $A$ Comment on the Traynor Plan for Revision of Federal Tax Procedure (1939) 27 Geo. L. J. 1038. Cf. Surrey, The Trajnor Plan-What It Is (1939) y7 Thxes 393; Surrey, Some Suggested Topics in the Field of Tax Administration (1940) 25 WAst. L, Q. 399. 
prior to the time he must go to trial before the Board. If the Technical Staff and the Revenue Agents in Charge were afforded as detailed and orderly a presentation of the taxpayer's case as is made to the Board, the number of administrative settlements would considerably increase. The protest requirement would serve to force complete presentation of the case in the administrative stage so that the Commissioner may have the adequate information which the presumption of correctness now accorded to his deficiency letters assumes he has obtained.

Other critics have contended that the tightening up of the protest requirement would obstruct the settlement of the $98.2 \%$ of the income tax controversies which are now settled administratively without the taxpayer's ever filing a petition with the Board. The proposed protest procedure, however, would in practice apply not to these cases, but to the $1.8 \%$, representing about 3,688 cases, settled administratively after petition to the Board, as well as to the 1,175 cases terminated by Board decision on the merits. ${ }^{9}$ It is precisely these cases which, however small a fraction they constitute of the total number of cases settled administratively, have placed huge amounts in litigation for an average period of five to six years. At the close of the fiscal year 1937-1938 there were 8,553 such cases pending before the Board and the courts that review its decisions, involving $\$ 5^{1} 3,985,520$. At the close of the fiscal year $193^{8-1939}$ there were 7,864 cases pending, involving $\$ 456,974,846$.

There have been vociferous objections that the issuance of findings of fact thereafter by the Commissioner would leave the taxpayer defenseless. Such objections give an ironic twist to a proposal intended entirely to ensure the taxpayer a clear statement of the reasons for any deficiency asserted against him. The Commissioner would be in a position, as he is not today, to make such a statement on the basis of a full factual disclosure. His statement would in no way preclude the taxpayer from submitting the same facts to the Board which might thereupon make findings contrary to those of the Commissioner. It is therefore wrong to conclude that the Commissioner's findings would be endowed with finality merely because they were distinguished by clarity.

\section{Judicial Procedure}

The present decentralization of the Bureau of Internal Revenue, together with: the proposed protest procedure, can do much to reduce that disheartening loss of time, money and certainty which has in the past rendered so unsettling the journey toward an administrative settlement. Such a revision in the administrative procedure is bound to have beneficial repercussions on the judicial procedure by contributing to the extrication of factual from legal issues. Nevertheless the fresh delays and uncertainties which beset the judicial consideration of a tax controversy indicate that there are likewise grave defects in the judicial procedure.

The decentralization of the Bureau of Internal Revenue places the entire administrative consideration of a case, including the issuance of the ninety-day deficiency

\footnotetext{
- At most, the protest would only be used in those cases in which deficiency letters are now issued. There were 10,241 deficiency letters issued under the income tax in the fiseal year 1937-1938, and 13,288 in 1938 -r939.
} 
letter, in the regional office, and the Appeals Division attorneys who represent the Commissioner before the Board are permanently stationed in such offices. The need for a corresponding decentralization of judicial hearings persists. While the Board now hears more than $90 \%$ of its cases outside of Washington, disposition of controversies is prolonged until enough of them accumulate in one region or another to justify a circuit trip. Such a trip disposes of a hearing only on the merits, and hearings on other grounds must still generally be heard in Washington. Thus, a motion to dismiss the complaint, a motion for a bill of particulars, a motion for an order that undenied allegations be deemed admitted in certain cases, a motion for a rehearing, a motion to settle the amount of a deficiency in accordance with the Board's opinion, a motion to settle the contents of the record for appeal, a motion to determine the place of trial, and many other motions must in practice be heard in Washington. While the new Federal Rules of Civil Procedure have served to modernize completely the procedure of the Federal District Courts, no corresponding revision has taken place in the Board's Rules of Practice. Such a revision is partially contingent upon an effective decentralization of the Board.

A feasible proposal for decentralizing the hearings of the Board of Tax Appeals has already been suggested. ${ }^{10}$ It provides for the establishment in each of five regional districts of a Board Division of three members having exclusive jurisdiction therein to make decisions on behalf of the Board and to dispose of procedural issues within the ambit of the new Federal Rules of Civil Procedure. Hearings could be held by a single member at various centers within the regions provided he consult with other members regarding a decision.

Such a decentralization of the Board, however, would be but one phase of a thoroughgoing revision of the whole judicial procedure in income, estate, and gift tax cases. In an ordinary judicial circuit a case progresses in orderly fashion along a single route to successively higher courts. In the judicial structure for tax cases hearings are held not only before the Board but before 85 District Courts and the Court of Claims, and there is no point of concentration for the consideration of like cases. The multiplicity of tribunals has increased the complexities of an already complex tax law and ridden it with inconsistencies. Since 1913 the federal courts have written about 6,000 reported tax decisions. Since its establishment in 1924 the Board of Tax Appeals has published about 9,500 opinions and issued about 4,500 unreported memorandum opinions. Exch year nearly 1,500 new tax cases are decided and the mass of precedents grows, and grows more puzzling:

At present the taxpayer may proceed either along the deficiency procedure through the Board of Tax Appeals, or the refund procedure through the numerous District Courts and the Court of Claims for the determination of his tax liability. The issue is the same in either case, but the differences hetween the two procedures are substantial enough to alter its determination. Differences in the respective statutes of limitations, in the methods of judicial review, in the operation of the doctrines of

\footnotetext{
${ }^{10}$ Traynor, supra note 1 , at 1425 .
} 
estoppel and the like all affect the outcome of the issue. Yet the choice of one procedure or the other is often accidental or governed by extraneous considerations. It may, for example, hinge upon whether the taxpayer, frequently unaware of the effect upon subsequent procedure, resolves a questionable point in his return in his own favor or not. While awaiting contest of his tax liability the taxpayer may elect either to withhold payment at the risk of having to pay interest in the event of an unfavorable decision, or to make payment in the knowledge that he will receive the interest thereon in the event of a favorable decision. This parallelism of the deficiency procedure and the refund procedure has resulted in a hodgepodge of proceedings against the Commissioner in the Board of Tax Appeals, suits against the Unifed States in the District Courts and the Court of Claims, and suits against the collectors in the District Courts. ${ }^{11}$ This duplication of judicial processes can be rationalized only by a nostalgic attachment for ancient forms.

The suit for erroneous refund constitutes still a third procedure which serves to multiply litigation. The Commissioner may assert a deficiency on the basis of one item. The taxpayer may pay the amount in question but within two years file a claim for refund based on another item. The Commissioner may upon investigation allow the claim, but within another two years announce that he will sue for erroneous refund on still a third item. The taxpayer may thereupon rechart the litigation by repaying the refund and filing a new claim for refund. Only if the claim is disallowed and the taxpayer litigates to obtain a judicial hearing does the matter eventually come to an end. Meanwhile neither the taxpayes nor the Commissioner can consider the tax year in question closed until the statutes of limitations have run with reference to the various procedures. A tax liability may thus hang fire for nearly twenty years.

Under such circumstances, the Board of Tax Appeals can do nothing, even though it was established for the purpose of affording a skilled review of these technical problems. While it hears the bulk of income, estate, and gift tax controversies, it is still powerless to review a case in the absence of a deficiency letter. It can never take its proper place in judicial tax procedure so long as it is but one of 87 tribunals of original jurisdiction whose decisions have equal weight as precedents.

The remedy for such a situation is as feasible as it is urgent. The deficiency and refund procedures could well be consolidated into a single administrative and judicial procedure. A taxpayer claiming to have erroneously oyerpaid his tax would be required to file a refund claim containing the same information as in the protest against an asserted deficiency. If the Commissioner disallowed the claim after conference, he would issue findings of fact containing the reasons for the disallowance. The taxpayer could appeal to the Board just as if he were contesting a deficiency. In a Board hearing he would be limited to the material in the refund claim as the Commissioner would be to the findings of fact. The same procedure would govern

\footnotetext{
${ }^{12}$ Forty percent of the refund cases filed in the District Courts are in the form of a suit against the collector. In such suits either party may demand a jury trial, an obsolescent proceeding invoked only four times in the fiseal year $1938-1939$ and five times in the preceding year.
} 
those situations where the Commissioner asserted a deficiency and the taxpayer thereupon paid the tax but contested the liability. If he paid the tax before filing a protest, he would be required thereafter to file-a refund claim. If he filed a protest first and paid the tax during the conference thereupon, that protest would merely take the place of the refund claim. The statute of limitations should be approximately the same on the filing of refund claims as on assessments so that neither the government nor the taxpayer would have any more advantage under one statute of limitations than under the other.

Once a tax liability for a particular year is placed in issue by either the Commissioner or the taxpayer, the subsequent consideration of his return should be conclusive as to his entire tax liability for that year, and any further deficiencies or refund claims should be barred irrespective of whether the statute of limitations has run or not. Where either party wished to concede some issues and at the same time continue consideration of others, partial disposition of such cases could be facilitated by a provision that the concession of certain issues did not preclude claims or deficiencies with respect to others. The final determination of the latter would determine the tax liability for the given year. ${ }^{12}$

The transfer of refund jurisdiction from the District Courts and the Court of Claims to the Board of Tax Appeals, together with the decentralization of the Board, would afford both taxpayer and government ready access to a judicial hearing uncomplicated by delays and uncertainties. Nevertheless these proposals have likewise aroused a buzz of criticism with a recurring refrain of admission that the present situation is far from satisfactory. The objections seem mere sentimental justifications of traditional procedures rather than realistic defenses. There is no reason why "confidence and cooperation between the citizen and his government" could not be maintained as well or better through the taxpayer's opportunity to appear before the Board as to appear before a District Court. The Board members are better qualified than the average District Court judge to hear a tax case and the guarantees thought to be inherent in life tenure could equally be provided.

The suggestion was made in conjunction with these proposals for the coordination of judicial review that taxpayers who file petitions with the Board of Tax Appeals be required to post a bond to guarantee the collectibility of any tax that might be found due. ${ }^{13}$ The posting of a bond by the taxpayer would be entirely in keeping with the present character of the Board, which has evolved from an informal administrative agency to a judicial tribunal, and it would guarantee the government against an annual average loss of over $\$ 2,000,000$ in revenue. Vehement objections have arisen to this suggestion on the ground that such a requirement would be rigid and harsh. Such criticism seems more emotional that convincing. The requirement of a bond could be waived whenever circumstances warranted it, as in such atypical situations as the Tex-Penn case. ${ }^{14}$ Actually, under the benefits that could be expected from the protest procedure, it would probably not apply to more than $15 \%$ of the

${ }^{12}$ Traynor, supra note 1 , at 1424 .

16 Helvering v. Tex-Penn Co., 300 U. S. 481, 491 (1937). 
taxpayers now filing petitions with the Board. No taxpayer would be required to post a bond exceeding the amount of the deficiency in question whereas the bond in lieu of payment now required on appeals to the Circuit Courts of Appeals, representing nearly one fifth of the cases closed by the Board, ${ }^{15}$ may be equal to double the amount of the deficiency in question.

The consolidation of original jurisdiction in the Board of Tax Appeals should be accompanied by a consolidation of appellate review. There can be neither uniformity nor certainty in the disposition of tax cases, so long as the decisions of the Board of Tax Appeals remain subject to review by ten Circuit Courts of Appeals and the Court of Appeals for the District of Columbia. ${ }^{16}$ Not only must the Board issue decisions subject to this multiple review but it must take into consideration the existing decisions of those eleven courts before issuing its own. It has no authoritative judicial guidance because it has eleven different guideposts, and the trails frequently lead to different destinations. If one court reverses a Board decision, it is still possible that another may subsequently uphold a similar decision. It may even happen that a single Board decision on several consolidated petitions may be simultaneously upheld and reversed if appeals are thereafter taken by the taxpayers or the Commissioner to different Circuit Courts of Appeals. ${ }^{17}$

With inevitable differences of opinion among the Circuit Courts litigation thrives and multiplies. A decision adverse to the taxpayers in one circuit leaves taxpayers in other circuits free to litigate comparable issues in the hope of obtaining a favorable decision. The Commissioner is under constant pressure to litigate, for a decision adverse to the government in one circuit may be counteracted by favorable decisions in another and a conflict may thus develop in which the Supreme Court will grant certiorari. Unless he is on guard to litigate in this manner he risks the loss of revenue, for the eleven winds of appellate review can blow capriciously in any direction. A plea which he advances unsuccessfully in one circuit may years later be successfully advanced by a taxpayer in another connection and another circuit, and the Commissioner's failure to try his luck in the interval may entail the loss of huge sums of revenue.

'It does not follow, however, that the winds which buffet a controversy about upon the stormy seas of litigation finally blow it into port. In the absence of a conflict, the Supreme Court rarely grants certiorari to review a tax case. The decision of - one circuit on an important issue may thus go unchallenged for years because no case presenting the same issue arises in another circuit. The Commissioner is not bound in other circuits by such a decision but if he endeavors to develop a conflict which

\footnotetext{
${ }^{28}$ Traynor, supra note $I$, at $1435,0.79$.

${ }^{10}$ It is specious to compare the Board with such agencies as the Securitics and Exchange Commission, the Federal Trade Commission or the National Labnr Relations Board. None of these agencies has-anything rlike the thossand cases decided annually by the Board. The bulk of cases appealed to the Circuit Courts by federal quasi-judicial agencies are from the Board. The proposed decentralization of the Board would afford a broader base than exists in the case of other agencics. Tax litigation, moreover, presents 2 unique problem in the discrepancy between the constitutional mandate of tax uniformity and the present lack of such uniformity in tax decisions. There is evidence of dissatisfaction even with the other agencies. See Traynor, stipra note 8 , at 1432-1433.

${ }^{17}$ Id. at 1407, n. 31 .
} 
will result in an authoritative determination by the Supreme Court, he is apt to incur the ill will of those taxpayers to whom the decision is favorable. In any event it is not easy to plan the strategy of litigation in such a manner as to produce a conflict which will prompt the Supreme Court to grant certiorari. A denial of certiorari, far from deciding an issue, leaves it more unsettled than ever by opening the door to further litigation in the courts below. In numerous instances the Supreme Court steps in after years of such litigation only to make a decision contrary to that of the Circuit Court in the original case. ${ }^{18}$ Thus in 1930 the Board of Tax Appeals held that a taxpayer could not deduct a loss on a sale of property to a corporation wholly owned by him.12 That decision was reversed by the Court of Appeals for the District of Columbia in $1934,{ }^{20}$ the Supreme Court thereafter denied certiorari, ${ }^{21}$ and the Second, Eighth and Ninth Circuit Courts of Appeals subsequently rendered similar decisions. ${ }^{23}$ In deference to these decisions, the Board allowed the deduction of such losses, ${ }^{23}$ but the Commissioner clung to the view that they were not deductible. In 1939 his view was confirmed by a decision of the Seventh Circuit Court of Appeals. ${ }^{24}$ The Supreme Court consequently granted certiorari and in 1940 held that such losses were not deductible. 25 Between the Board's consideration of the issue and the Supreme Court's determination there intervened a decade of delay and uncertainty, which may even yet not be ended. ${ }^{28}$ The history of the tax status of improvements made by a lessee is another example of the inconclusiveness of denial of certiorari. In 1919 the Supreme Court denied certiorari to a decision that held such improvements were not taxable income to the lessor at the termination of the lease: $^{2 a^{2}}$ There followed two decades of confusion as taxpayers and the Bureau sought to evolve a workable rule within the margin afforded by that decision. ${ }^{20^{b}}$ The issue was at last squarely faced by the Supreme Court in $194^{\circ}$ and in Helvering $v$. Brutun $^{26^{c}}$ it permitted taxation to the lessor upon termination of the lease, a decision which if rendered in 1919 would have prevented much litigation and tax uncertainty.

${ }^{18}$ Id. at 1409, n. 34 .

${ }^{20}$ Jones v. Helvering, 71 F. (2d) 214 (App. D. C. 1934).

13 B. B. Jones, 18 B. T. A. 1225 (1930).

$=3$ Helvering v. Jones, 293 U. S. 583 (I934).

${ }^{22}$ Commissioner v. Eldridge, 79 F. (2d) 629 (C. C. A. 9th, 1935); Commissioner v. MeCreery, 83 F. (2d) 817 (C. C. A. 9th, 1936); Foster v. Commissioner, 96 F. (2d) r30 (C. C. A. 2d, 1938); Smith v. Higgins, 102 F. (2d) 456 (C. C. A. 2d, 1939); Helvering v. Johnson, 104 F. (2d) 140 (C. C. A. 8th, 1939). Perhaps the Seventh Circuit Court of Appeals should be added to the list: Commissioner v. Edward Securities Co., 83 F. (2d) 1007 (C. C. A. 7th, 1936), af'g per curiam, Edward Securities Corporation, 30 B. T. A. 918 (I934).

${ }^{12}$ E.g., Corrado \& Galiardi, 22 B. T. A. 847 (1931); A. S. Eldridge, 30i B. T. A. 1322 (1934), af'd, Commissioner v. Eldridge, 79 F. (2d) 629 (C. C. A. 9th, 1935); Ralph Hochstetter, 34 B. T. A. 791 (1936).

"Commissioner v. Griffiths, 103 F. (2d) I10 (C. C. A. 7th, 1939), rev'g George W. Grifiths, 37 B. T. A. 314 (1938).

${ }^{35}$ Higgins v. Smith, 60 Sup. Ct. 355 (1940); cf. Griffiths v. Helvering, 60 Sup. Ct. 277 (19.40), aff'g Commissioner v. Griffiths, 103 F. (2d) 110 (C. C. A. 7th, 1939).

${ }^{20}$ Uncertainties persist in view of the four-to-four affrmance in Helvering v. Johnson, 6o Sup. Ct.

293 (1940), of the decision in Helvering v. Johnson, 104 F. (2d) 140 (C. C. A. 8th, 1939), allowing

the loss where the taxpayer's wife owned $49 \%$ of the stock in the vendee corporation.

${ }_{202}$ Miller v. Gearin, 258 Fed. 225 (C. C. A. 9th, 1919), cert. den. 250 U. S. 667 (1919).

${ }^{20 b}$ Traynor, supra note $\mathrm{I}$, at $1408, \mathrm{n} .33$.

${ }_{30 e} 60$ Sup. Ct. $632(2940)$. 
The drafting of the revenue acts becomes increasingly difficult in the midst of the present maze of complicated legal doctrines and inconsistent decisions. The issues which arise under the revenue acts, necessarily intricate despite their skilful draftsmanship, are not clarified by myriad considerations in the present overlapping processes of administrative and judicial review. If they receive expert hearings, they need not receive endless hearings, and they can proceed expeditiously in an atmosphere of cooperation and a framework of coordinated procedure to determinations at least as true as those which would result from a long period of litigation. Many a tax problem is now no nearer solution after half a dozen Circuit Courts of Appeals have battled over it than when the first court pronounced its judgment, and both parties must mark time until the Supreme Court finally selects some one of several equally reasonable alternatives as the right solution.

Administrative rulings which are ceaselessly subject to the interpretations of a complex judicial system lose much in effectiveness and clarity. An administration overwhelmed by too much law cannot adequately instruct the large personnel required to administer the revenue acts. Similarly small taxpayers cannot thread their way through the complicated maze of tax law without expensive legal assistance. Even taxpayers who can afford such assistance find their business or personal transactions beset by uncertainties while they await long-delayed clarification.

Appellate review could feasibly be limited to a single Court of Tax Appeals established either as a separate tribunal or through the enlargement of the Court of Appeals for the District of Columbia or the Court of Claims. ${ }^{27}$ This Court of Tax Appeals would be obliged to hear all appeals from the decisions of the various Board Divisions, so that any conflict at this juncture could be immediately resolved. It could hold periodic hearings in various geographic centers for the convenience of taxpayers. Both the Commissioner and taxpayer would then ordinarily be bound by its decision. Appeal therefrom would be by certiorari to the Supreme Court and a denial of certiorari would settle a question instead of renewing litigation as it does under the present system.

Certain critics have raised a constitutional objection on the ground that the proposed Court of Tax Appeals would not be a constitutional court, and the routing of tax cases to it would accordingly lack due process of law. Such an intermediate court, however, could be constituted as a constitutional court if this were necessary. ${ }^{28}$ If only ultimate consideration by a constitutional court is needed, the Supreme Court itself would afford such review. ${ }^{2 \delta}$ The weight of authority in any event appears to

27 Traynor, supra note $x$, at 1430 .

${ }^{28}$ Ex parte Bakelite Corporation, 279 U. S. 438 (1929), holding the Court of Customs Appeals, now the Court of Customs and Patent Appeals, and Williams v. U. S. 289 U. S. 553 (1933), holding the Court of Claims, to be legislative courts, rely mainly on the historical treatment of the subjects dealt with by these courts. O'Donoghue v. U. S., 289 U. S. 516 (1933), likewise rests heavily upon history in finding the Court of Appeals for the District of Columbia to be both a constitutional and a legislative court. The argument of history would, as regards taxation, seem to permit Congress to create a constitutional court to hear only tax cases if it so desired. It would appear that Congress possesses the power to choose one or the other type of court in this regard and therefore could make its intentions clear as to the choice adopted.

${ }_{30}$ Cf. Anniston Mfg. Co. v. Davis, 301 U. S. 337 (1937). 
rest with the proposition that there would be no denial of due process to a taxpayer even if his case were reviewed by a legislative court.created under the revenue powers of Congress..$^{30}$.

An attachment persists in some quarters to the present delay and uncertainty on the ground that they contribute in the end to the judicially "right" solution. Even if it were conceded, however, that there can be but a single solution to each complicated tax problem, there can be no advantage in delaying it for an average of eight to nine years. The Supreme Court could give more effective consideration to the few cases of enough consequence to merit review if it were relieved of the necessity of passing upon. an endless stream of technical tax matters which might more appropriately be determined by a tribunal with specialized knowledge thercof. There need be little fear that under such a procedure tax problems would be considered in isolation from general substantive law. The members of the proposed Board divisions, by virtue of their permanent residence in a given area, would be exceptionally well situated to decide issues turning on the substantive law of that area. As a matter of fact, approximately only $10 \%$ of the issues in tax cases turn on questions of lecal substantive law, which for the most part could be settled by reference to the case or statutory law of the jurisdiction involved. Fewer cases probably turn on principles of general substantive law than is frequently asserted, and even these might well be referred to a specially qualified tribunal.

There will always be those who cling to any system that has worked, no matter how cumbersomely, on the ground that it is wise to leave bad enough alone. Fear of change may serve to maintain the present administrative and judicial procedure just as-lethargy has in the past. Meanwhile taxpayers may wait patiently for the bloom of settlemert upon the century-plant of litigation, in the long pariods of delay and attendant uncertainties which effectively nullify that uniformity of taxation shich the Constitution prescribes.

\section{A Pretestive Tax Policy axd Prospectire Closing Agreesients}

Along with the improvement of settlement procedure, much can be accomplished through tax policy designed to prevent controversies from arising. While they cannot be prevented altogether, it is possible to reduce the area in which they occur. Thus, for many years there was a productive source of litigation in the inequitable situations arising from a change of front after the statute of limitations had removed any danger from the consequences of such change for earlier years. The cure for such litigation was not the development of a speedier and more orderly process of determination but the removal of its cause, and Congressional recognition of this fact led to the adoption of Section 820 of the Revenue Act of $193^{8.32}$ This section

so Cf. the statenients in Ex parte Bakelite Comporation, 279 U. S. 338 (1929), both as to the treatment of claims against the United States $(p .+52)$ and the creation of the Court of Customs Appeals by Congress under its powers to lay and collect dutics on imports and to adopt any appropriste means of earrying that power into execution (p. 460 ).

${ }^{31}$ Now lNT. Rev: CoDe $\$ 3801$. See generally Maguire, Surrey and Traynor, Section 820 of the Revenue ACt of $193^{8}$ (1939) $4^{8}$ YAlx L J. 509, 719; Kent, Wivigution of the Statuse of Linsirations in Federal Tax Cases (1939) 27 Caufr. L Rev. 109. 
serves to reduce greatly such litigation by mitigating the hardships produced by the operation of the statute of limitations and thus removing the economic pressure and revenue loss which motivated the litigation.

The provisions allowing deductions for bad debts and losses on worthless stock are another fruitful source of litigation. Here the remedy may lie in statutory revision designed to remove the present obstacles to obtaining the deduction by eliminating the charge-off requirement and modifying the statute of limitations. ${ }^{32}$ A thoroughgoing analysis of the issues most frequently in controversy between taxpayers and the government would undoubtedly uncover other weaknesses in the statutes which can be cured only by substantive action.

Revision of the revenue acts is not the only way to prevent controversy at its source. Some way must be found to correct the anomalies of a revenue system in which the government enacts complex statutes and promulgates equally complex regulations without affording any guide to their interpretation, and then forces the taxpayer to construe them at his peril. Necessarily complicated statutory provisions and regulations, unusual fact situations, new business conditions, are bound to present taxpayers with tax questions difficult of resolution. But the very intricacy of the problems only heightens the taxpayers' need for definite solutions, so that they may plan their business and family affairs in an atmosphere of certainty. Economic and social waste inevitably results from a system in which solutions are finally attained only by arduous controversies in administrative offices and judicial forums. The denial by the Bureau of Internal Revenue of expected tax consequences generally leads the taxpayer to resort to litigation in an effort to obtain from the courts a confirmation of those consequences. Yet for years the policy of the Bureau was characterized by a steadfast refusal to issue rulings, on contemplated transactions. ${ }^{33}$ If, for example, a question arose as to whether a corporate exchange involving millions and occasioned by business necessity apart from taxation was or was not a tax-free exchange, the Bureau passed upon it only after the exchange had been consummated. Its caution sprung from an awareness that the rulings of one Commissioner would not be binding upon the same or a successor Commissioner, as the Couzens case demonstrated, ${ }^{34}$ a fear that the Bureau might:be compelled to answer case after variant case until the taxpayer discovered the most favorable situation, and an apprehension that it mignt otherwise be tricked into rulings harmful to the. revenue.

The advocates of a preventive tax policy were aware of these considerations but regarded them as outweighed by the advantages that would follow from a system of declaratory administrative rulings. Their position was that taxpayers faced with a complex law had the right to know where the Bureau stood on a given issue and to act in reliance upon such information with the assurance that the Bureau would have no subsequent change of heart. The basic question centered upon whether administrative guidance should come before the transaction in the form of a binding ruling

23 Cf. Paul, Studies in Federaz Taxation (1937) 235.

${ }^{88}$ Mimeo. 4589, 1937-1 Cum. BuLl. 536. 
or after the event in the guise of a deficiency letter. It seemed possible to anticipate the dangers in the first system of abuse on the taxpayers' side by giving the Commissioner complete control over the issuance of such rulings, and in the Revenue Act of 1938 Congress determined in favor of declaratory administrative rulings. ${ }^{\mathbf{3 s}}$

This important decision on policy, however, was accomplished in the statute by the mere deletion of eight words in the section providing for closing agreements, and it has therefore received scant attention. A "closing agreement" is an agreement betwcen the taxpayer and the Commissioner with respect to tax liability, approved by the Secretary of the Treasury, the Under Secretary, or an Assistant Secretary, and by statute made final as respects both taxpayer and government. ${ }^{30}$ It may relate to any internal revenue tax, to the total tax liability for a tax year or to the tax consequences of any particular transaction, and to issues of law or to issues of fact. Before 1938 it could be made only for "any taxable period ending prior to the date of the agreement." 37 It thus served merely to impart to the agreed tax consequences of completed transactions a finality in advance of that which would eventually ensue from the operation of the statute of limitations. In 1938 the words "ending prior to the date . of the agreement" were deleted, s8 so that a closing agreement may now relate not only to a past tax year already closed, but also to a present tax year not yet terminated, or to a future tax year not yet commenced. This simple change makes possible a thoroughgoing system of declaratory administrative rulings in the form of binding agreements between the government and the taxpayers requesting the rulings. An agreement not only informs the taxpayer of the Burcau's position regarding a proposed transaction but enables him to rely on it thereafter, for under the statute the agreement is binding forever.

While this policy of declaratory administrative rulings is still in its infancy, its wisdom has been amply demonstrated. The tax consequences of approximately fifty contemplated transactions have been determined by the Bureau and given permanent confirmation in closing agreements. ${ }^{39}$ In about thirty other instances when the taxpayers concerned wished merely to ascertain the Bureau's position on a transaction, the Bureau has issued rulings with respect to contemplated transactions . without entering into closing agreements. The great majority of the agreements and rulings relate to the tax-free exchange sections of the Internal Revenue Codereorganizations, recapitalizations, liquidations, and other corporate exchanges: The remaining cases present a wide-variety of contemplated transactions such as the present or March 1, 1913 value of property or securities which the taxpayer intends to sell, taxability of a stock dividend, the amount of income that would be realized

\footnotetext{
${ }^{23}$ Report of a House Ways and Means Subcommintee on A Proposed Revision of the Revenue Laws (1938) 55, 79; H. R. REP. No. 1860, 75th Cong., 3d Sess. (1938) 67.

se Closing agreements are now provided for in $\$ 3760$ of the Internal Revenue Code. See, generally, Surrey, Same Suggested Topics in the Field of Tax Administration (1940) 25 Wass. L. Q. 399.

3f Revenue Act of 1928, 5606 . 28 Revenue Act of 1938, 5801 .

39 The actual number of agrecments concluded in a litule more than a year and 2 half is about one thousand, as one transaction may involve many agreemerts. Thus, on a reorganization agreements may be obtained from all stockholders involved as well as from the corporations concerned.
} 
on a cancellation of indebtedness, the tax status of a proposed pension trust, the treatment of bond discount, and the amount of corporate earnings and profits.

Certain procedural norms and policy standards have already been developed in regard to these innovations. A declaratory ruling or closing agreement on a contemplated transaction will not be considered unless the taxpayer can show that a bona fide business or family exigency motivates the transaction regarding the tax consequences of which he seeks an opinion. Rigid adherence to this condition, necessary to prevent the Bureau from becoming either a gigantic information burean or a sounding-board for tax-dodging schemes, has served to discourage abuses.0

The ruling or agreement must relate to a definite set of facts or a definite course of future conduct. There has been littie difficulty on this score, for the taxpayer requesting the administrative action nearly always supplies full information and an investigation in the field can be utilized to supply any necessary additional data. Control over facts and conduct is supplied by limiting the agreement to specified matters and by making the taxpayer's request part of the agreement under a proviso that any misstatement of fact shall render the agreement void. The ascertainment of precise and complete factual data is essential to closing agreements with regard to past years, for otherwise a proper tax may be foregone or an unjustified tax imposed. These difficulties are not characteristic of future closing agreements, since incomplete or inaccurate information simply makes the agreement inapposite to the actual facts and hence of no cperative effect. A careful check can insure that the completed transaction is the same as the contemplated transaction on which the ruling was made.

If a ruling is embodied in a closing agreement, it is rendered secure for all time against shifts in statutory interpretation, whether occasioned by judicial decision or administrative action. The Bureau benefits from this certainty as well as the taxpayer, for the closing agreement prevents the latter from urging that a different tax consequence be ascribed to the completed transaction. As Congress, however, had no intention of providing certainty at the sacrifice of its legislative freedom, both the Regulations and each particular closing agreement state that the agreement is subject to any future change in the statutory law.11

The Bureau has been feeling its way with caution in evolving standards on its most difficult question of policy, that of determining the kinds of -transactions in which declaratory administrative rulings will be issued. While much here depends on the particularities of the given case, the consideration of a few general classes may serve to illustrate the problem.

The taxpayer may request a ruling with regard to a contemplated transaction, but all the facts relevant to the ruling may be in the past. He may, for example, plan to sell some stock; the stock has passed through several reorganizations and corporate distributions; the question is the proper basis for determining gain or loss on the

\footnotetext{
"In many of the cases, especially those in the reorganization field, the agent investigating the retura would formerl $g$ have requested a ruling on the transaction, so that issuance of a ruling in advance of the unasaction does not inrolve an added burden.

${ }^{42}$ U. S. Tiens REG. 103, App. par. 47.
} 
intended sale. The ruling is here declaratory only in the sense that it is occasioned by an event still in the future. The question to be ruled upon involves only completed transactions. Of the situations currently being passed upon, less than $20 \%$ are of this type. The remaining requests for rulings relate to transactions completely in the future, both as to the taxable event itself and the matters upon which the determination must turn. Thus, corporatiors $A$ and $B$ are planning to merge; the details of the proposed merger are fully described; the question is whether a merger of that nature is a tax-free exchange. While the relevant facts here exist only on paper, they are precise and certain so that the ruling refers to a course of conduct which is definite even though it is in the future.

Another taxpayer, however, may request a ruling that reaches into a future that is highly problematic. He may contemplate construction of a plant to manufacture a product whose market, according to his predictions, may exist for only a few years after which the plant will then be obsolete. A question then arises as to the deduction to be taken each year for obsolescence. Here the factors on which the ruling must depend may be so conjectural as to preclude a binding agreement on the part of the Bureau.

From another perspective, a problem arises as to the period of time during which a transaction will have tax consequences. At one end of the scale is the transaction which has but a single consequence. The taxpayer plans to sell certain property; the question is the gain or loss on the contemplated sale. Transactions of this nature as a rule present no problems, for the force of the ruling is spent with the completion of the transaction. Next on the scale is the transaction which possesses one tax consequence in the year of consummation and another in some future year. Thus, if the contemplated transaction is a reorganization, a ruling that it is cast in the form of a tax-free exchange determines not only the tax consequence of the reorganization itself but also the basis of the properties and stock involved on their later disposition. Here also little difficulty arises, for the tax consequence in the latter year is a necessary corollary of the tax consequence for the year of the transaction and consistency of treatment is the guiding principle. ${ }^{42}$

Cases at the other end of the scale give concern, however, for they involve transactions which have tax consequences throughout a number of future years. Taxpayer $A$ plans to establish a trust in which he will retain only the power to control the flow of income to the various beneficiaries without himself being able to obtain the income; he requests a ruling that the income is not taxable to him as grantor. If the zuling is granted and made binding for the life of the trust, taxpayer $A$ has permanent insurance against a shift in judicial and administrative interpretation. Taxpayer $B$ who created a similar trust but did not secure a ruling will not possess such immunity. It is hardly desirable to place one group of taxpayers beyond the reach of changing judicial interpretation and to leave other taxpayers subject to the expanding concepts of income tax liability. In the case of the sale, such lack of uniformity is not

\footnotetext{
"Closing agreements relating to such transactions in practice deternirie both questions.
} 
serious for the difference in treatment is transitory. Nor is it of much moment in the reorganization case, for here one taxpayer merely pays tax at the time of the exchange and the other upon disposition of the stock received on the exchange. $A$ serious discrimination arises, however, if one taxpayer is accoided the privilege of non-taxability on trust income for a score of years when others must pay taxes on comparable income.

Other cases of this nature come to mind. A taxpayer may wish to transfer its factory to a possession of the United States, but before doing so seeks a ruling that products manufactured in such possession will be tax free if sold in the United States. If a closing agreement to this effect were made and the courts thereafier ruled otherwise, the taxpayer covered by the agreement will have secured a permanent competitive advantage. Taxpayers may contend with much merit that tax certainty is highly important in the initiation of long-range transactions of this nature. They may note that all of the facts relevant to the tax decision can be stated with definiteness, and are not dependent upon prophecy, as in depreciation or obssolescence situations. The advantage of certainty nevertheless seems outweighed by the disadvantage of lack of uniformity. There is already ccinsiderable dissatisfaction with the judicial decision to apply the principle of res adjudicata to tax cases, ${ }^{43}$ and it would seem that Congress acted wisely in giving the-Bureau of Internal Revenue full discretionary power with respect to the issuance of declaratory administrative rulings. ${ }^{\text {"4 }}$ There is much to be said for expanding the scope of closing agreements, but the expansion should proceed at a controlled and temperate rate.

Several aspects of future closing agreements may be briefly noted in comparison with proposals that have been made for another declaratory ruling system. This latter system would involve a complete statutory structure and the issuance of declaratory rulings on a wide front. A ruling requested by one taxpayer would be made applicable to all taxpayers similarly situated by giving them notice of a hearing on the proposed ruling. Once issued, and the transaction consummated, the ruling could be questioned in the courts by any taxpayer affected, and other interested taxpayers could intervene in the ensuing litigation. ${ }^{45}$

There are three main differences between this proposal and the system of closing : agreements. The former would be complex and would rest on a statutory framework; it would contemplate both individual and class rulings; it would allow the taxpayer to obtain judicial review of the ruling upon completion of the transaction to which it relates. The system of closing agreements, by contrast, is basically simple but subject to clastic development through administrative experimentation. Insofar as individual rulings are concerned, and most of the requested rulings would be of this nature, the personalized closing agreement is eminently satisfactory. If the ruling is of such a broad nature as to be applicable to numerous taxpayers, it can easily be put

\footnotetext{
az Cf. Patz, Selected Stedies in Federar Taxatiox (2d Scries, 1938) $104,140$.

“H. R. REP. No. 1860, 75th Cong., 3d Sess. (1938) 67.

4s Oliphant, Dedaratory Rulings (1938) 24 A. B. A. J. 7; Traynor, Dedsratory Relings (1938) 66 Tax Mac. 195.
} 
into effect by the issuance of a Treasury Regulation. Reliance upon such a Regulation may be protected by resort to Section 379r(b) of the Internal Revenue Code, which would permit a possible change in the Regulation to operate only prospectively.to Finally the closing agreement is binding upon the taxpayer as well as the government.

A system of declaratory administrative rulings can well be premised upon administrative finality in the freld of advance opinions. The value of such a system would be impaired by shackling the administrative agency with litigation, much of which might prove sterile if the transactions were dropped. ${ }^{47}$ Freedom from litigation afier consummation of the transaction should also be assured the administrative agency. If the taxpayer does not like a ruling, he can simply avoid its acceptance by not entering into a closing agreement. For its part the Bureau would. not be bound by a ruling that the taxpayer does not accept. If the taxpayer should agree with the -ruling it is fair enough that he forego resort to the courts in the event of a later change of heart. inc-ipening of the question would impose a new burden on the administrative agency and render unavailing the purpose of closing agreements to reduce excessive litigation. The extension of such agreements seems destined to do more than any proposed system of declaratory rulings toward affording taxpayers that authoritative guidance and protection which they have so long needed.

"See, generally, Surrey, The Scope and Efict of Treasuri Regulations Under the Inconie, Enste and Gift Taxes (1940) $88 \mathrm{U}$. of PA. L. REv. 556, 567, at seq.: PALz, op. cit. supro note 43, at 72 st seg. Cf. Revenue Act of 1926, $51108(\mathrm{~b})$, which, perhaps crronoously, has been omitted from the Internal Rerenue Code, and $53792(2)(2)$, which in its new setting appears to possess a scope much wider thap was presumably intended when the section was first enacted in 1868 .

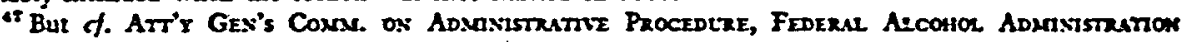
(Mon. No. 5, 1940) 20-22, and Port Office Depaxturext (Mon. No. 13, 1940) 88-9x, which seem to assume that judicial review in advarce of the transaction is ac integral part of a system of declaratory administrative rulings. 